\title{
Viability of creating a water agency in the Grande river basin, Bahia
}

\author{
Viabilidade de criação de uma agência de água na bacia do Rio Grande, Bahia
}

\author{
Kalesson Martins de Alencar ${ }^{1}$, Michel Castro Moreira ${ }^{1}$ and Demetrius David da Silva ${ }^{2}$ \\ ${ }^{1}$ Universidade Federal do Oeste da Bahia, Barreiras, BA, Brasil \\ ${ }^{2}$ Universidade Federal de Viçosa, Viçosa, MG, Brasil \\ E-mails: kalesson@ufob.edu.br (KMA),michelcm@ufob.edu.br(MCM),demetrius@ufv.br (DDS)
}

Received: December 09, 2017 - Revised: April 27, 2018 - Accepted: June 03, 2018

\begin{abstract}
The work was developed from the analysis of the viability of creating a water agency in the Grande river basin, located in western Bahia, Brazil. The charging mechanisms of five different water agencies in Brazil were applied to the basin. The simulations showed the possibility of an average annual collection in the basin of over $\mathrm{R} \$ 2.2$ million, which would provide a median value above $\mathrm{R} \$ 160,000$ per year for administrative costs of the agency. Thus, considering that the median value of the annual administrative cost to state agencies is close to $\mathrm{R} \$ 300,000$, the collection provided by the mechanisms studied would not initially allow the creation of a water agency for the Grande river basin. However, the adoption of one of the existing water agencies would be a more appropriate alternative for the implementation during a shorter period of time, given the technical and operational structure within which the current agencies function.
\end{abstract}

Keywords: Water resources management; Water price; Water charging mechanisms.

\section{RESUMO}

O trabalho foi desenvolvido a partir da análise da viabilidade de criação de uma Agência de Água na bacia hidrográfica do rio Grande, localizada no Oeste do Estado da Bahia. Foram aplicados à bacia os mecanismos de cobrança pelo uso de recursos hídricos de cinco diferentes Agências de Água do país. As simulações demonstraram a possibilidade de uma arrecadação anual média na bacia de mais de $\mathrm{R} \$ 2,2$ milhões, o que proporcionaria para custeio administrativo da agência, um valor mediano superior a $\mathrm{R} \$ 160$ mil anuais. Desse modo, considerando que o valor anual mediano do custeio administrativo das agências estaduais estudadas situa-se próximo a R \$300 mil, a arrecadação proporcionada pelos mecanismos utilizados não viabilizaria, inicialmente, a criação de uma Agência de Água para a bacia hidrográfica do rio Grande. No entanto, a adoção de uma das agências de água existentes seria uma alternativa mais adequada de ser efetivada, em menor espaço de tempo, haja vista a estrutura técnica e operacional de funcionamento das agências atuais.

Palavras-chave: Gestão de recursos hídricos; Cobrança pelo uso de recursos hídricos; Mecanismos de cobrança. 


\section{INTRODUCTION}

The water agencies are part of the National System of Water Resources Management (SINGREH), being its creation authorized by the competent water resources council, upon request of the river basin committee, once its financial viability is ensured by charging for the use of water resources (BRASIL, 1997). Working as the Executive Secretariat of the Watershed Committee $(\mathrm{CBH})$, the agencies carry out technical, financial and administrative functions, as well as the joint development within a model of shared management of water resources (ANA, 2011).

The Brazilian experience shows that the country has private entities created or selected to be Water Agency, such as the Paraíba do Sul River Basin Water Management Association (AGEVAP), the PCJ Agency Foundation, the Executive Association of Support for the Management of Hydrographic Basins Peixe Vivo (AGB PEIXE VIVO), the BioAtlantic Institute (IBIO-AGB Doce), the Foundation of the Alto Tietê River Basin (FABHAT), the Araguari River Basin Agency (ABHA) and the Vale do Itajaí Water Agency Foundation (ANA, 2011).

There are also various public bodies eventually in water agency functions, such as the National Water Agency (ANA), the Department of Water and Power of the State of São Paulo
(DAEE) and the Water Resources Management Company of the State of Ceará (COGERH). In ANA (2014, p. 26),

$[\ldots]$ this model of public bodies with agency function, has made possible the necessary basis for the implementation of committee-agency systems, decentralized and supported by funds raised by charging for the water use.

The imposition of water agencies and charging for the use of water resources takes on greater importance in areas where there is intensive use of water, as occurs in the Grande river basin, located in the west of the state of Bahia. Thus, the object of the present study was to analyze the feasibility of creating a water agency in the Grande river basin in order to provide subsidies for the discussion and the creation of an agency for the basin.

\section{MATERIAL AND METHODS}

\section{Study area}

The Grande river basin (Figure 1) shows an area approximately $78,500 \mathrm{~km}^{2}$, corresponding to $13.9 \%$ of the area of the state of Bahia (ALMEIDA; MOREIRA; SILVA, 2014). The Grande river

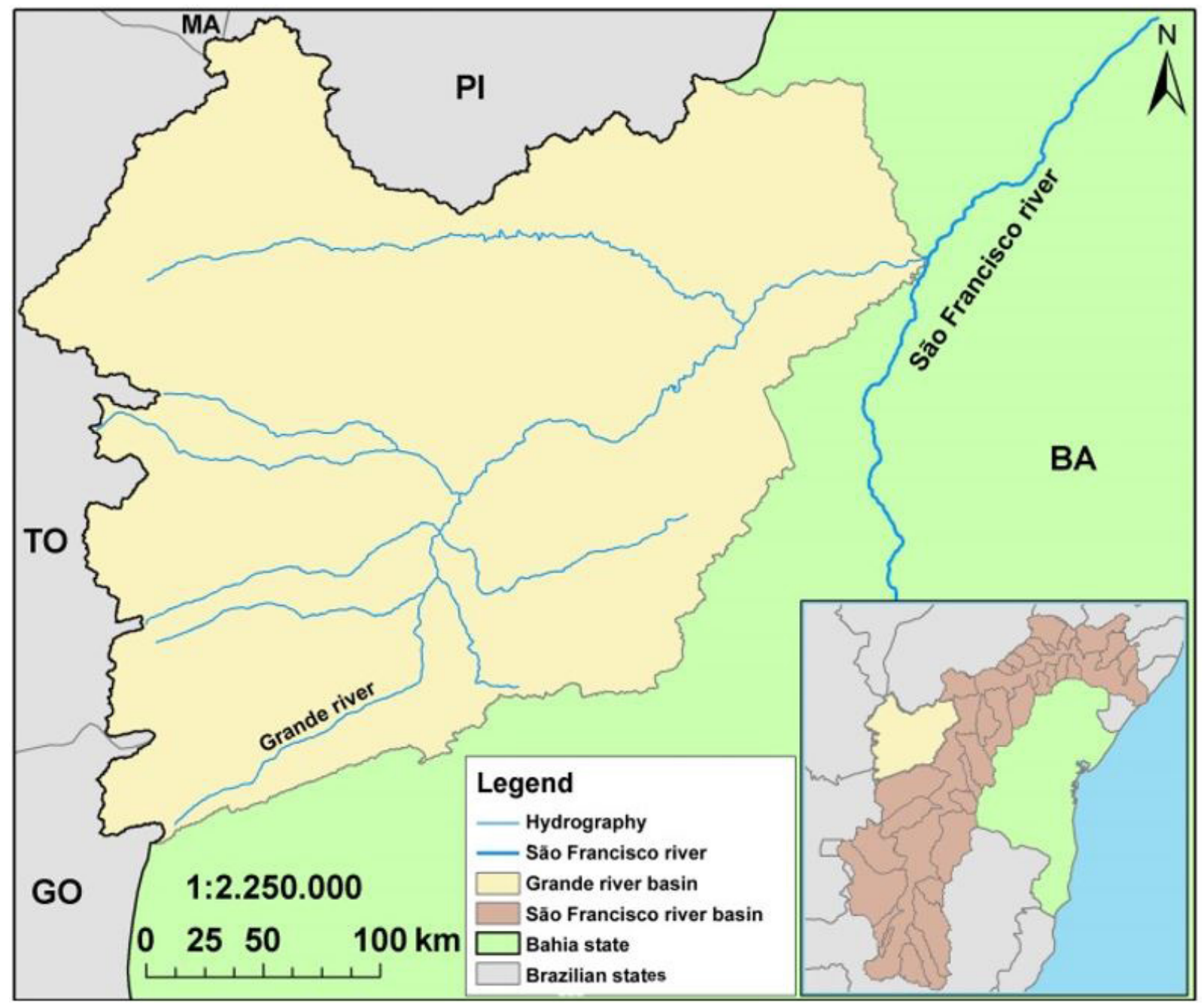

Figure 1. Location of Grande river basin. 
produces the third largest water source flowing into the São Francisco river basin (PEREIRA et al., 2007); however, there are conflicts over the use of water, which demand an adequate management of its water resources (ALMEIDA; MOREIRA, 2013).

The Grande River Basin Committee (CBH-Grande), created by Decree $n^{\circ} .11,246$, October 172008 , includes 17 municipalities in the western part of the state of Bahia. In 2015 the CBH-Grande approved the creation of the Technical Chamber of Granting and Collection and is developing its plan of water resources, important steps for the establishment of charging for the use of water resources in the basin.

\section{Survey of data on the granting of rights to use water resources}

Considering that the use of water resources subject to the granting of rights of use of water resources will be charged and considering that the Grande river basin only has rivers within the state domain, the data regarding the granting of the basin were obtained with the Direction of Regulation (DIREG), of the Institute for the Environment and Water Resources (INEMA), once INEMA is the managing body of water resources of the state of Bahia. The data were made available by physical means (Official DIREG no. 02764/2015) and in digital format.

The information provided includes the number of the process, the type of impound, the purpose of the use, the municipality of the grant, the location coordinates, the number of the ordinance, the date of publication in the Official Gazette of the State of Bahia (DOE-BA), the flow granted and the type of release of use (concession, authorization or dispensation). A preliminary treatment was performed in the data that consisted of the pre-processing of the grants and the consistency analysis.

The pre-processing comprised the analysis of the database provided by DIREG, which corresponded to the grants issued by INEMA until September 2015. The concession of water resources in the state of Bahia is granted in cases of public utility, and authorization is granted in other cases. Considering that the concession of a grant may have the maximum period of validity of 30 years, while the authorization is of a maximum of four years (BAHIA, 2007), an analysis was carried of the grants whose concessionary orders were issued from September 1985 and authorization as of September 2011, were issued. The grants of other years were discarded.

The consistency analysis for the current grants was made through the identification of possible failures, such as the existence of extreme or null values. In the case of inconsistency, the values were updated based on the DOE-BA's concession granting research.

Up to September 2015, the Grande river basin had 171 current concessions, with a total flow of $1,479,774,188.9 \mathrm{~m}^{3}$ year-1 or $46.9 \mathrm{~m}^{3} \mathrm{~s}^{-1}$. Of these, 80 are for irrigation $\left(687,233,628.9 \mathrm{~m}^{3}\right.$ year $\left.^{-1}\right)$; 24 , for animal watering $\left(1,860,040 \mathrm{~m}^{3}\right.$ year $\left.^{-1}\right) ; 20$, for human supply $\left(1,904,205 \mathrm{~m}^{3}\right.$ year $\left.^{-1}\right) ; 16$, for sanitation ${ }^{1}\left(404,720,395 \mathrm{~m}^{3}\right.$ year $\left.^{-1}\right)$; 28 , for industrial supply $\left(5,569,170 \mathrm{~m}^{3}\right.$ year $\left.^{-1}\right)$; two for sand

Flows provided the water and sewage utility, being 1,066,485 $\mathrm{m}^{3}$ day $^{-1}$ intended for the dilution of effluents. mining $\left(54,750.00 \mathrm{~m}^{3}\right.$ year $\left.^{-1}\right)$; and one for the small hydroelectric power station-PCH $\left(378,432,000 \mathrm{~m}^{3}\right.$ year $\left.^{-1}\right)$.

\section{Analysis of the viability of creating a Water Agency in the Grande river basin}

In order to analyze the feasibility of creating a water agency in the Grande river basin, the amounts charged for the use of water resources were evaluated, including the maintenance costs of an agency, and the legal requirements for charging in the Grande river basin.

The amounts that can be charged were calculated considering current concessions in the basin as of September 2015 and the parameters and equations obtained in CEIVAP (2014), COMITÊS PCJ $(2007,2012)$, CBHSF $(2008,2010)$ and CBH-DOCE (2011).

The costs of maintaining a water agency, considering the year 2015, were obtained from the agencies linked to the committees of the Paraíba do Sul river basin (CEIVAP); Piracicaba, Capivari and Jundiaí (PCJ); São Francisco (CBHSF); Doce (CBH-DOCE); and Alto Tietê, in the State of São Paulo.

The surveyed water agencies, referring to the aforementioned river basin committees, were the Paraíba do Sul River Basin Water Management Association (AGEVAP); the PCJ Agency Foundation; the Executive Association of Support for the Management of Hydrographic Basins Peixe Vivo (AGB PEIXE VIVO); the BioAtlantic Institute (IBIO-AGB DOCE); and the Foundation of the Alto Tietê River Basin (FABHAT).

The values of the resources deriving from the collection and the administrative costing of the agencies were obtained in AGEVAP (2015a,b), São Paulo (2016), AGB PEIXE VIVO (2016a,b), Brasil (2016), ANA (2016) and CBH-AT (2015).

Based on data for charging, the resources collected and the maintenance cost of each of the respective agencies, the percentage representation of the administrative cost of the agencies in relation to the resources collected from the charging of water resources was calculated.

The representativeness of the administrative costing of water agencies was analyzed, based on the limit for resource use established in art. 22 \ 1 of Law $n^{\circ} .9,433 / 1997$ (7.5\% of the collection), the resources that could be made available for the administrative cost of an agency in the Grande river basin were calculated.

An analysis of the resources available for administrative costs of a water agency in the Grande river basin was carried out, compared to the average cost of the basin agencies under study. It was analyzed whether the proceeds from the collection in the basin would be sufficient to bear the costs of setting up an agency or adopting a pre-existing agency.

Considering that the institution of charging and a water agency, in addition to financial matters, demands the fulfillment of legal requirements, the perspective of the institution of the charging for the use of water resources in the Grande river basin were evaluated, considering the existence of the water resources plan and the creation of technical commissions to study and implement the charging.

Considering that the Grande river is state-owned domain, the legal requirements for the institution of charging under the 
Bahia State Law no ${ }^{\circ}$ 11,612 / 2009 and the Bahia State Water Resources Council (CONERH-BA) Resolution no. 01/2005 were analyzed. The precepts established in Federal Law no. 9,433/1997 were also considered.

Thus, the creation of the river basin committee, the drafting of the basin water resources plan by the river basin committee, and the approval of the basin plan by the competent Water Resources Board are requirements for the institution of charging (BRASIL, 1997; BAHIA, 2005, 2009).

\section{RESULTS AND DISCUSSION}

The values charged and collected, the administrative costs and the representativeness of the administrative costs of the Association for the Management of Waters of the Paraíba do Sul River Basin (AGEVAP), the PCJ Agency Foundation, the Executive Association for the Management of the Hydrographic Basin Peixe Vivo (AGB PEIXE VIVO), the BioAtlantic Institute (IBIO-AGB DOCE) and the Alto Tietê River Basin Agency Foundation (FABHAT), for the year 2015, are presented in Table 1. In the charging of resources, the effective transfer of the managing body to the agencies, the income from financial investments and the balance of the previous year were considered.

Considering the values presented in Table 1, it is important to note that AGEVAP was created in 2002 to be the executive secretariat of CEIVAP and in 2004, it incorporated the functions of the water agency from the edition of Provisional Measure $\mathrm{n}^{\circ}$. 165/2004, converted into Law $n^{\circ}$. 10,881/2004 (AGEVAP, 2012). To date, AGEVAP has management contracts with ANA, the State Institute of the Environment of Rio de Janeiro (INEA) and the Institute of Water Management of the Minas Gerais State (IGAM). In the management agreement with INEA, for example, this body performs the functions of water agency, among others, for the river basin committees of the rivers Paraíba do Sul (MPS) and Piabanha.

The same situation happened with AGB PEIXE VIVO, which was created in 2006 to act as a water agency for the Velhas
River Basin Committee (CBH-VELHAS), subsequently incorporating another tributary of the São Francisco river, CBH-PARÁ and, finally, the CBHSF.

The figures presented in Table 1 show a federal average collection of over $\mathrm{R} \$ 49$ million and administrative expenses of the agencies of two million, representing $4.8 \%$ of the water use charging. At a state level, the results show an average collection above 16 million and an average administrative cost of 570 thousand, representing $4.5 \%$ of the charging resources. In general, considering federal and state river basin agencies, there is an average collection of 33 million and administrative costs of 1.3 million, which represents $4.7 \%$ of the resources collected from the water use charging.

In view of the extreme amounts of charging and collection shown in Table 1, where there is a federal collection of $\mathrm{R} \$ 80$ million, and the other $\mathrm{R} \$ 20$ million, the median allowed to represent the reality of the distribution of values. As a result, the average administrative costing of the agencies was $\mathrm{R} \$ 1,917,465.56$ (Federal), R \$316,048.59 (State) and $\mathrm{R} \$ 1,263,161.41$ (federal and state agencies).

It is important to note that Peixe Vivo Agency/CBHSF, among the federal basins, presented the highest administrative cost. This factor can be justified by its higher collection and, mainly, by the coverage of the São Francisco river basin.

At the state level, the CBH-MPS and CBH-Piabanha stand out because they have the lowest administrative costs, which can be explained by the fact that these committees have formalized a management contract with AGEVAP, taking advantage of the existing administrative, technical and operational capacity of the agency.

It should be noted that it is common for a single water agency to manage the resources of more than one basin, such as AGEVAP, which works with CEIVAP and four affluent committees to the Paraíba do Sul river (CBH Médio Paraíba do Sul, Commitee Piabanha, CBH Rio Dois Rios and CBH Baixo Paraíba do Sul and Itabapoana), including the Peixe Vivo Agency, which represents CBHSF, CBH-VELHAS, CBH-PARÁ and CBH-VERDE GRANDE.

Table 1. Representativeness of the administrative costs of the Water Agencies of the committees CEIVAP, PCJ, CBHSF, CBH-DOCE and CBH-AT for 2015.

\begin{tabular}{|c|c|c|c|}
\hline Water Agency & $\begin{array}{c}\text { Collection resources } \\
\left(\mathrm{R} \$ \mathrm{ano}^{-1}\right)\end{array}$ & $\begin{array}{c}\text { Adm. Costing } \\
\left(\mathrm{R} \$ \text { ano }^{-1}\right)\end{array}$ & $\begin{array}{c}\text { Adm. Costing } \\
(\%)\end{array}$ \\
\hline AGEVAP/CEIVAP & $20,617,937.37$ & $1,171,585.61$ & 5.7 \\
\hline PCJ basins & $21,582,338.21$ & $1,354,737.20$ & 6.3 \\
\hline \multicolumn{4}{|l|}{ Agency } \\
\hline AGB PEIXE VIVO/CBHSF & $87,012,115.83$ & $3,279,350.13$ & 3.8 \\
\hline IBIO AGB-DOCE & $68,027,046.55$ & $2,480,193.92$ & 3.6 \\
\hline Federal Average & $49,309,859.49$ & $2,071,466.72$ & 4.8 \\
\hline Federal Median & $44,804,692.38$ & $1,917,465.56$ & 4.7 \\
\hline AGB PEIXE VIVO/CBH-Velhas & $38,578,495.71$ & $493,589.21$ & 1.3 \\
\hline AGEVAP CBH-MPS & $5,103,654.18$ & $138,507.97$ & 2.7 \\
\hline AGEVAP Piabanha & $1,858,663.21$ & $129,653.78$ & 7.0 \\
\hline FABHAT & $21,714,795.00$ & $1,527,782.00$ & 7.0 \\
\hline State Average & $16,813,902.03$ & $572,383.24$ & 4.5 \\
\hline State Median & $13,409,224.59$ & $316,048.59$ & 4.8 \\
\hline Overall Average & $33,061,880.76$ & $1,321,924.98$ & 4.7 \\
\hline Overall Median & $21,648,566.61$ & $1,263,161.41$ & 4.7 \\
\hline
\end{tabular}

Source: adapted from AGEVAP (2015a,b); São Paulo (2016); AGB PEIXE VIVO (2016a,b); Brasil (2016); Minas Gerais (2016); ANA (2016); and CBH-AT (2015). 
The amounts collected from the charging for the use of water resources must be used for, in addition to the financing of projects and works included in the water resources plan of the basin, the payment of implementation expenses and administrative costs of the organs and entities that are members of SINGREH, including the water agencies, but limited to $7.5 \%$ of the total collected (BRASIL, 1997).

Even the values of administrative costs between the basins taken as example being quite distinct, the data provides a reference for the analysis of the feasibility of implementing a water agency in the studied basin.

It is important to emphasize that the basins used as reference are in regions where there is a greater diversification of the water uses among users, which differs from the reality of the Grande river basin, where there is the predominant use of irrigated agriculture.

Table 2 presents the resources that can be charging considering different mechanisms and the maximum administrative cost that could be used to pay implementation expenses and administrative costs for the creation of a water agency to provide administrative, technical and financial support to the Grande River Basin Committee (CBH-Grande).

The simulation presented in Table 2 shows an average collection of more than $\mathrm{R} \$ 2.2$ million, which would make resources available in the average of $\mathrm{R} \$ 170,000$ for administrative costs of the agency. The mechanism of the state of São Paulo was disregarded in the analysis, in view of the extreme values generated and their inapplicability to the reality of the Grande river basin, due to the lack of a specific coefficient for agriculture.

Considering that the average administrative cost of state agencies is close to $\mathrm{R} \$ 600$ thousand (Table 1 ), the collection provided by the mechanisms studied does not initially make it possible to create a water agency for the Grande river basin, considering the generation of resources for administrative costings in the order of $\mathrm{R} \$ 170$ thousand, on average, not reaching this level, in addition to the costs to implement the infrastructure necessary for the proper functioning and maintenance of qualified technical staff.

The simulated value of charging by the CBHSF mechanism was different from the CEIVAP and PCJ mechanisms, but similar to the CBH-DOCE. The factor that justified the difference in the calculated amounts was the coefficient for irrigation, animal husbandry and aquaculture $(\mathrm{Kt})$, whose value of 0.025 lowers

Table 2. Simulation of resources that can be charged and used for the administrative costing of the water agency in the Grande river basin.

\begin{tabular}{|c|c|c|c|}
\hline Mechanism & $\begin{array}{l}\text { Simulated } \\
\text { value of } \\
\text { charging } \\
\left(\mathrm{R} \$ \text { ano }^{-1}\right)\end{array}$ & $\begin{array}{l}\text { Adm. Costing } \\
\left(\mathrm{R} \$ \text { ano }^{-1}\right)\end{array}$ & $\begin{array}{c}\text { Adm. } \\
\text { Costing } \\
(\%)\end{array}$ \\
\hline CEIVAP & $2,933,118.25$ & $219,983.87$ & 7.5 \\
\hline PCJ & $3,831,665.43$ & $287,374.91$ & 7.5 \\
\hline CBHSF & $949,160.85$ & $71,187.06$ & 7.5 \\
\hline CBH-DOCE & $1,358,294.10$ & $101,872.06$ & 7.5 \\
\hline Average & $2,268,059.65$ & $170,104.47$ & 7.5 \\
\hline Median & $2,145,706.17$ & $160,927.96$ & 7.5 \\
\hline
\end{tabular}

substantially the collection by the CBHSF and, consequently, the available value for administrative costings.

Considering this aspect, the mechanism used in the São Francisco river, of which the Grande river is its affluent, is what gives less collection potential. Therefore, the Grande river basin committee should consider the implications of adopting such a mechanism.

The resources for administrative costing derived from the simulation of charging by the CEIVAP mechanism, and mainly by the PCJ, reach levels similar to the median cost of the state agencies and may enable the creation of a water agency to exercise the function of executive secretariat of $\mathrm{CBH}-\mathrm{Grande}$, or the adoption of one of the existing agencies, which is an easier alternative to be implemented in a shorter time, given the pre-existence of technical and operational structure of functioning.

In the case of the option to create the water agency, the authorizations by the Water Resources Board and the institution of the charging are required to guarantee the financial viability for the maintenance of the agency (BAHIA, 2009; BRASIL, 1997). The Grande river basin has an operation committee, but has not yet implemented the charge for the use of water resources.

In order to implement the charging, approvals of the Water Resources Plan by the Grande River Hydrographic Basin Committee (CBH-Grande) and the Bahia State Water Resources Council (CONERH) are required. In Bahia, CBH-Grande has one of the most advanced processes for the charging institution, since this committee is finalizing its Water Resources Plan (CBHSF, 2015). In addition, another important stage for the charging was implemented, with the creation of a Technical Chamber of Granting and Charging by the basin committee in the second half of 2015 (BAHIA, 2015).

The institution of the charging in the Grande river basin can provide benefits to the users of water of the basin due to the better management of the water resources and the accomplishment of projects that promote the environmental recovery. On the other hand, the collection is still poorly seen by the water user segments, which would require better disclosure of their objectives so that it can fulfill its role as a rational water use and to obtain financial resources to finance the programs and interventions included in the water resources plans.

It is important to note that the simulated charging values may have been underestimated due to the possibility of users in the basin using water without the respective grant. As an updated and representative grant database affects charging calculations, the charging mechanisms used may not have been sensitive to the actual use of the water in the basin. Therefore, in order to implement the charging, campaigns are needed to register users of water resources in the basin.

In Moreira et al. (2012, p. 12), it is necessary a

$[\ldots]$ greater control over the uses of water without the respective legal instrument, since the abstraction of water without its authorization compromises the actions of the managing body with regard to the quantitative and qualitative control of the water in a basin, as well as to charging for the use of water. 
Regarding the applicability of the mechanisms used in the study, it is worth highlighting the fact that they were developed and are being adopted in regions with significant differences in relation to the conditions of the Grande river basin, in which there is the intense use of water by the agricultural sector. Thus, in order to carry out the charging, it is necessary, within the framework of $\mathrm{CBH}-\mathrm{Grande}$, to discuss a mechanism appropriate to the conditions of the basin.

In addition, for the creation of a water agency, it is necessary to consider the impacts that the financial noncompliance by the user segments could generate in the maintenance of the agency. Although the historical data of the charging in the country shows that the value of the collection is close to the amount charged, representing $96.2 \%$ (ANA, 2015), in case of higher noncompliance can compromise the functioning of the water agency.

Thus, considering the amounts that can be charged and estimated values for administrative costing, it is verified that the financial viability for the adoption of an existing agency can be assured by the institution of the charging for the use of water resources in the Grande river basin.

\section{CONCLUSION}

From the analysis of the results, it can be concluded that the collection provided by the charging mechanisms for the use of water resources studied does not initially make it possible to create a water agency for the Grande river basin. However, it would allow the adoption of one of the existing water agencies, given the pre-existence of technical and operational structure of functioning.

\section{ACKNOWLEDGEMENTS}

To the National Council for Scientific and Technological Development (CNPq) and the State of Bahia Foundation for Research Support (FAPESB) for financial support.

\section{REFERENCES}

AGB PEIXE VIVO - ASSOCIAÇÃO EXECUTIVA DE APOIO À GESTÃO DE BACIAS HIDROGRÁFICAS PEIXE VIVO. Relatório gerencial das demonstrações financeiras CBHSF 2015. Belo Horizonte, 2016a. 3 p.

AGB PEIXE VIVO - ASSOCIAÇÃO EXECUTIVA DE APOIO À GESTÃO DE BACIAS HIDROGRÁFICAS PEIXE VIVO. Relatório gerencial das demonstrações financeiras CBH-Velhas 2015. Belo Horizonte, 2016b. 2 p.

AGEVAP - ASSOCIAÇÃO PRÓ-GESTÃO DAS ÁGUAS DA BACIA HIDROGRÁFICA DO RIO PARAÍBA DO SUL. Avaliação da implementação da cobrança pelo uso de recursos bídricos de domínio da união na bacia hidrográfica do rio Paraíba do Sul: período 2003/2011. Resende, 2012.
AGEVAP - ASSOCIAÇÃO PRÓ-GESTÃO DAS ÁGUAS DA BACIA HIDROGRÁFICA DO RIO PARAÍBA DO SUL. Demonstrativo de execução físico-financeira. Resende, 2015a. 3 p.

AGEVAP - ASSOCIAÇÃO PRÓ-GESTÃO DAS ÁGUAS DA BACIA HIDROGRÁFICA DO RIO PARAÍBA DO SUL. Prestação de contas: exercício 2015. Resende, 2015b. 1224 p.

ALMEIDA, W. A.; MOREIRA, M. C. Índices de conflito pelo uso da água na bacia do rio Grande. In: SIMPÓSIO BRASILEIRO DE RECURSOS HÍDRICOS, 20., 2013, Bento Gonçalves, RS. Resumos... São Paulo: Associação Brasileira de Recursos Hídricos, 2013. 303 p.

ALMEIDA, W. A.; MOREIRA, M. C.; SILVA, D. D. Applying water vulnerability indexes for river segments. Water Resources Management, v. 28, n. 12, p. 4289-4301, 2014. http://dx.doi. org/10.1007/s11269-014-0745-5.

ANA - AGÊNCIA NACIONAL DE ÁGUAS. Comitê de bacia hidrográfica: o que é e o que faz? Brasília: Superintendência de Apoio à Gestão de Recursos Hídricos, 2011. 16 p.

ANA - AGÊNCIA NACIONAL DE ÁGUAS. Cobrança pelo uso de recursos hídricos: capacitação em recursos hídricos. Brasília, 2014. 85 p. v. 7.

ANA - AGÊNCIA NACIONAL DE ÁGUAS. Cobrança pelo uso de recursos hídricos no Brasil: informativo 2014. Brasília, 2015. 28 p.

ANA - AGÊNCIA NACIONAL DE ÁGUAS. Cobrança pelo uso de recursos hídricos de domínio da União na bacia hidrográfica do rio Doce. Brasília, 2016. Disponível em: < http:/ /www2.ana.gov.br/Paginas/ servicos/cobrancaearrecadacao/BaciaDoce_Inicial.aspx $>$. Acesso em: 11 abr. 2016.

BAHIA. Conselho Estadual de Recursos Hídricos do Estado da Bahia - CONERH-BA. Resolução CONERH no 01/2005. Plano Estadual de Recursos Hídricos (PERH/BA). Diário Oficial do Estado, Salvador, BA, 22 mar. 2005. 10 p.

BAHIA. Superintendência de Recursos Hídricos do Estado da Bahia - SRH. Instrução Normativa $n^{\circ} 1$, de 27 de fevereiro de 2007. Dispõe sobre a emissão de outorga de direito de uso dos recursos hídricos de domínio do Estado da Bahia, assim como a sua renovação, ampliação, alteração, transferência, revisão, suspensão e extinção, e dá outras providências. Diário Oficial do Estado, Salvador, BA, 27 fev. 2007.

BAHIA. Lei Estadual no 11.612 de 8 de outubro de 2009. Dispõe sobre a Política Estadual de Recursos Hídricos, o Sistema Estadual de Gerenciamento de Recursos Hídricos, e dá outras providências. Diário Oficial do Estado, Salvador, BA, 11 out. 2009. 43 p.

BAHIA. Secretaria do Meio Ambiente do Estado da Bahia SEMA. Cobrança do uso da água é tema de reunião do CBH Rio Grande, em Barreiras. Salvador, 2015. Disponível em: <http://www. meioambiente.ba.gov.br/2015/08/10612/Cobranca-do-uso- 
da-agua-e-tema-de-reuniao-do-CBH-Rio-Grande-em-Barreiras. html>. Acesso em: 8 mar. 2016.

BRASIL. Lei Federal nº 9.433 de 8 de janeiro de 1997. Política Nacional de Recursos Hídricos. Diário Oficial [da] República Federativa do Brasil, Brasília, DF, 9 jan. 1997.13 p.

BRASIL. Execução da receita e despesa contrato de gestão $n^{\circ} 72 /$ ANA/2011. Diário Oficial [da] República Federativa do Brasil, Brasília, DF, 1 abr. 2016.

CBH-AT - COMITÊ DA BACIA HIDROGRÁFICA DO ALTO TIETÊ. Deliberação CBH-AT n. ${ }^{\circ}$ 06/2015. São Paulo, 2015. 12 p.

CBH-DOCE - COMITÊ DA BACIA HIDROGRÁFICA DO RIO DOCE. Deliberação CBH-DOCE n. 26 de 31 de março de 2011. Governador Valadares, 2011. 8 p.

CBHSF - COMITÊ DA BACIA HIDROGRÁFICA DO RIO SÃO FRANCISCO. Deliberação CBHSF n. ${ }^{\circ}$ 40/2008. Belo Horizonte, 2008. 9 p.

CBHSF - COMITÊ DA BACIA HIDROGRÁFICA DO RIO SÃO FRANCISCO. Deliberação CBHSF n. ${ }^{\circ}$ 56/2010. Belo Horizonte, 2010.3 p.

CBHSF - COMITÊ DA BACIA HIDROGRÁFICA DO RIO SÃO FRANCISCO. Cobrança pelo uso das águas em debate no Conselho Nacional de Recursos Hídricos. Belo Horizonte, 2015. Disponível em: $<$ http://cbhsaofrancisco.org.br/cobranca-pelo-uso-das-aguasem-debate-no-conselho-nacional-de-recursos-hidricos $>$. Acesso em: 8 mar. 2016.

CEIVAP - COMITÊ DE INTEGRAÇÃO DA BACIA HIDROGRÁFICA DO RIO PARAÍBA DO SUL. Deliberação CEIVAP n. ${ }^{\circ}$ 218/2014. Resende, 2014. 16 p.
COMITÊS PCJ - COMITÊS DAS BACIAS HIDROGRÁFICAS DOS RIOS PIRACICABA, CAPIVARI E JUNDIAÍ. Deliberação Conjunta dos Comitês PCJ n. ${ }^{\circ}$ 78/2007. Piracicaba, 2007. 10 p.

COMITÊS PCJ - COMITÊS DAS BACIAS HIDROGRÁFICAS DOS RIOS PIRACICABA, CAPIVARI E JUNDIAÍ. Deliberação dos Comitês PCJ n. ${ }^{\circ}$ 160/2012. Piracicaba, 2012. 8 p.

MINAS GERAIS. Detalhamento da execução físico-financeira do contrato de gestão n. ${ }^{\circ}$ IGAM/001/2011. Diário Oficial do Estado, Belo Horizonte, MG, 31 mar. 2016.

MOREIRA, M. C.; SILVA, D.; PRUSKI, F.; LARA, M. Índices para identificação de conflitos pelo uso da água: proposição metodológica e estudo de caso. Revista Brasileira de Recursos Hídricos, v. 17, n. 3, p. 7-15, 2012. http://dx.doi.org/10.21168/rbrh.v17n3.p7-15.

PEREIRA, S. B.; PRUSKI, F. F.; SILVA, D. D.; RAMOS, M. M. Estudo do comportamento hidrológico do rio São Francisco e seus principais afluentes. Revista Brasileira de Engenharia Agricola e Ambiental, v. 11, n. 6, p. 615-622, 2007. http://dx.doi.org/10.1590/ S1415-43662007000600010.

SÃO PAULO. Demonstrações financeiras Fundação Agência PCJ. São Paulo, 2016. p. 141-143.

\section{Authors contributions}

Kalesson Martins de Alencar: Literature review, research development, writing and formatting technical note.

Michel Castro Moreira: Advisor, collection and analysis of the database of grants and final review.

Demetrius David da Silva: Co-advisor, discussion of the results and review. 